\title{
The 2009 International Psychogeriatric Association Junior Research Awards in Psychogeriatrics
}

To open volume 22 of International Psychogeriatrics we take great pleasure in publishing the papers submitted by the three recipients of the 2009 International Psychogeriatric Association (IPA) Junior Research Awards in Psychogeriatrics. As you can see from our new 2010 front cover, all of them accepted their prizes in person on Tuesday 1 September 2009, at the opening session of the IPA $14^{\text {th }}$ International Congress in Montreal, Canada, where they were congratulated by George Grossberg (chair of the 2009 IPA Junior Research Awards committee) and Serge Gauthier (chair of the 2009 IPA $14^{\text {th }}$ Congress). One of the highlights of the Congress was the plenary session on the afternoon of Thursday 3 September, which I was privileged to chair, at which the three prize recipients presented their research findings to a large and appreciative audience.

These awards are open to researchers within five years of the award of their terminal degree (e.g. MD, $\mathrm{PhD}$ ), who are not above instructor or assistant professor level at the time of submission and have not won one of these awards before. All entrants are required to report previously unpublished original research. In addition to publication of their papers in International Psychogeriatrics, the 2009 winners received complimentary congress registration, \$US1500 to assist with expenses and a complimentary one-year IPA membership package.
In 2009 the awards attracted 24 entries from 13 countries, which the judges first whittled down to seven finalists, before selecting the three best from among these seven very strong contenders. The judging panel was chaired by George Grossberg (U.S.A.), former president of IPA, and also included myself (David Ames, Australia) acting in my role as editor-in-chief of International Psychogeriatrics, Glenna Dowling (U.S.A.), Engin Eker (Turkey), Agneta Nordberg (Sweden) and Byoung Hoon Oh (Republic of Korea). All 24 submitted papers had merit, but the judges had a tough time splitting the seven finalists, with the first five place-getters all being separated by the narrowest possible margin of one vote each. Our three winners have diverse geographic origins (Hong Kong, Sweden and Australia) and professional backgrounds, and they represent some of the best and brightest of the coming generation of researchers in psychogeriatrics. Like previous prize-winning papers, I expect these three publications to be heavily cited and their authors to become respected leaders in our field within a short period of time. I extend my heartiest congratulations to the three of them and sincere commiserations to the 21 runners up.

\section{DAVID AMES}

Editor-in-chief, International Psychogeriatrics

Melbourne, Australia

Email: ipaj-ed@unimelb.ed.au 